\title{
Antimicrobial spectrum activity of bacteriocinogenic Staphylococcus strains isolated from goat and sheep milk
}

\author{
Samane Rahmdel, ${ }^{1}$ Seyed Shahram Shekarforoush, ${ }^{1 *}$ Saeid Hosseinzadeh, ${ }^{1}$ Sandra Torriani, ${ }^{2}$ \\ and Veronica Gatto ${ }^{2}$ \\ ${ }^{1}$ Department of Food Hygiene and Public Health, School of Veterinary Medicine, Shiraz University, Shiraz, Iran, PO Box 71441-69155 \\ ${ }^{2}$ Food Microbiology Laboratory, Department of Biotechnology, University of Verona, Strada Le Grazie 15, 37134 Verona (VR), Italy
}

\section{ABSTRACT}

Bacteriocins have attracted great attention as potential alternatives to antibiotics and chemical food additives. In the present study, 243 Staphylococcus isolates from milk samples $(\mathrm{n}=110)$ of goat and sheep herds located in Fars province, Iran, were screened for antimicrobial substance production. Twenty-eight isolates showed an antagonistic activity against the indicator strain Micrococcus luteus ATCC 4698. The susceptibility of all antimicrobial substances to proteolytic enzymes allowed us to consider them as bacteriocin-like inhibitory substances (BLIS). The term BLIS is applied to uncharacterized proteinaceous antimicrobials produced by gram-positive bacteria. Based on molecular identification methods, the isolates belonged to the species Staphylococcus chromogenes, Staphylococcus epidermidis, Staphylococcus haemolyticus, Staphylococcus pseudintermedius, Staphylococcus aureus, and Staphylococcus agnetis. Pulsed-field gel electrophoresis revealed a high level of genotype diversity among the Staph. chromogenes isolates. All of the isolates harbored nukA or bsaA2 genes, suggesting that their BLIS were related to nukacin or Bsa. The antimicrobial compounds from test strains were not effective against gram-negative pathogens, including Salmonella enterica serovar Typhimurium, Escherichia coli O157:H7, and Klebsiella pneumonia as well as the indicator mold Aspergillus fumigatus. All the gram-positive targets, including Bacillus cereus, Listeria monocytogenes, Enterococcus faecalis Ef37 (a tyramine-producer strain), Lactobacillus saerimneri $30 \mathrm{a}$ (a histamine-producer strain), and methicillin-resistant Staph. epidermidis, were inhibited by the Staph. chromogenes isolates. Staphylococcus haemolyticus $4 \mathrm{~S} 12$ was able to inhibit the majority of gram-positive bacteria. Listeria monocytogenes strains

Received July 19, 2018.

Accepted November 25, 2018.

*Corresponding author: shekar@shirazu.ac.ir were the only indicators sensitive to the antimicrobial agents produced by Staph. agnetis 4S97B. The other Staphylococcus strains were ineffective on all the organisms tested. Based on their inhibitory capacities, the BLIS produced by the Staph. chromogenes isolates seem to be interesting candidates for developing novel antimicrobial agents.

Key words: antimicrobial activity, bacteriocin, bacteriocin-like inhibitory substance, Staphylococcus

\section{INTRODUCTION}

Concerns are growing over the rise of antibioticresistant microorganisms and the future inefficiency of current therapies. These problems highlight the need to search for alternative strategies. On the other hand, the interest in biopreservation of food has considerably increased due to the adverse effects of chemical preservatives on human health. Well-characterized bacterial peptides with antimicrobial activity, referred to as bacteriocins, have the potential to be used both in medicine and in the food industry (Varella Coelho et al., 2007; García et al., 2010; Balciunas et al., 2013). Yet-uncharacterized bacterial compounds with inhibitory effects, like those of bacteriocins, are defined as bacteriocin-like inhibitory substances (BLIS; Bastos et al., 2009).

Compared with the classical antibiotics, bacteriocins display a narrow spectrum of activity, which is thought to exert less pressure to develop antimicrobial resistance (Sandiford and Upton, 2012). Furthermore, the bacteriocin-producing strains often possess immunity to their own products through specific mechanisms, which may help limit resistance development as a result of sharing similar immunity genes (Jack et al., 1998; Daly et al., 2010; Sandiford and Upton, 2012; de Souza Duarte et al., 2013). These antimicrobial agents are generally recognized as safe substances, are nontoxic on eukaryotic cells, and become inactivated by digestive proteases, having little influence on the gut microbiota (de Souza Duarte et al., 2013). 
Many bacteriocins have been characterized so far, but to date the only bacteriocins approved for use as food additives are nisin and pediocin PA-1. Furthermore, bacteriocin-containing products that are commercially available to prevent mastitis are based on nisin (Wipe Out, ImmuCell, Portland, OR), lacticin 3147, or macedocin ST91KM (Kim et al., 2010; Braem et al., 2014). The ineffectiveness of nisin in some food matrices (e.g., meat) and the emergence of nisin-resistant bacteria would, however, compromise its efficacy as an antibacterial agent (de Souza Duarte et al., 2013). The identification of novel bacteriocins has attracted considerable research attention. Compared with the bacteriocins produced by lactic acid bacteria, little consideration has been given to those produced by Staphylococcus strains, which are referred to as staphylococcins.

Like the other bacteriocins, staphylococcins are currently assigned to 4 major classes. Class I bacteriocins, posttranslationally modified peptides, are divided into several subgroups, including lantibiotics and sactibiotics (Potter et al., 2014; de Souza Duarte et al., 2018). Epidermin, Pep 5, epilancin K7, epicidin 280, epidermicin NI01, and epilancin 15X are well-known lantibiotics produced by Staphylococcus epidermidis. The nukacintype lantibiotics have been previously reported to be produced by the species Staphylococcus warneri and Staphylococcus hominis. The lantibiotics staphylococcin C55, gallidermin, and hominicin have been isolated from Staphylococcus aureus, Staphylococcus gallinarum, and Staph. hominis, respectively (Sandiford and Upton, 2012; Götz et al., 2014). Hyicin 4244 is the first sactibiotic reported in staphylococci (de Souza Duarte et al., 2018).

Class II bacteriocins are small peptides without any posttranslational modifications. Aureocins 53 and A70 are the most common nonlantibiotic staphylococcins described in Staph. aureus. Class III bacteriocins include large, heat-labile antimicrobial proteins such as lysostaphin. Class IV bacteriocins are defined as cyclic peptides, characterized by the covalent linkage between their carboxy and amino termini. Aureocyclicin 4185 is the only class IV staphylococcin that has already been detected (Potter et al., 2014).

The antimicrobial activity of staphylococcins is mainly due to pore formation in the cytoplasmic membrane and to cell wall inhibition or lysis. They have been shown to be effective against a wide range of gram-positive and gram-negative bacteria, including food-spoilage and pathogenic strains, as well as antibiotic-resistant organisms. Due to their broad-spectrum antimicrobial activity, staphylococcins have the potential to be used as alternatives to the current antibiotics and food pre- servatives (Bastos et al., 2009). In the present study, the antimicrobial activity of bacteriocinogenic Staphylococcus isolates from milk samples of goat and sheep herds located in Fars province, Iran, was investigated to detect bacteriocins with potential biotechnological applications.

\section{MATERIALS AND METHODS}

\section{Sample Collection}

Between June and August 2016, 110 raw milk samples (70 goats and 40 sheep) were aseptically collected from 50 different herds located in 4 geographical areas of Fars province, Iran. The samples were hand-collected in sterile plastic vials after disinfecting the teat and discarding the first few streams of milk. They were then transferred to the microbiology laboratory under refrigerated conditions $\left(4-6^{\circ} \mathrm{C}\right)$ within 4 to $6 \mathrm{~h}$ of collection time and analyzed immediately.

\section{Isolation of Staphylococci}

All samples were processed by both enrichment and direct plating culture. The enrichment procedure included the initial centrifugation of milk samples $(10,000$ $\times g$ for $15 \mathrm{~min}$ at $4^{\circ} \mathrm{C}$ ) followed by resuspension of the pellet in Giolitti-Cantoni broth (Merck, Darmstadt, Germany) containing potassium tellurite (Merck) as a selective reagent and anaerobic incubation (with a layer of sterile paraffin) at $37^{\circ} \mathrm{C}$ for $48 \mathrm{~h}$; all cultures, whether blackened or not, were subsequently streaked onto Baird-Parker agar (Merck) supplemented with egg yolk-tellurite emulsion (Merck). Simultaneously, $0.1 \mathrm{~mL}$ of each sample was spread over the surface of Baird-Parker agar plates. All the plates were then incubated under aerobic conditions at $37^{\circ} \mathrm{C}$ for 24 to $48 \mathrm{~h}$. Suspected colonies were subcultured to the same medium and identified by positive Gram stain, the presence of catalase, and the absence of oxidase. For further confirmation of the isolates, PCR was performed, targeting the tuf gene using a set of Staphylococcus-specific primers, TstaG422 (5'-GGCCGTGTTGAACGTGGTCAAATCA-3') and Tstag765 (5'-TIACCATTTCAGTACCTTCTGGTAA-3'; Morot-Bizot et al., 2004). For DNA preparation, $1.5 \mathrm{~mL}$ of a 24 -h brain-heart infusion (BHI) broth (Merck) culture was pelleted by centrifugation for $5 \mathrm{~min}$ at $10,000 \times g$ at $4^{\circ} \mathrm{C}$. The pellet was washed with distilled water. It was then resuspended in $600 \mu \mathrm{L}$ of TE buffer $(10 \mathrm{~m} M$ Tris, 1 $\mathrm{m} M$ EDTA, $\mathrm{pH}$ 8.0) and subjected to DNA extraction as proposed by Fontana et al. (2005). The purity and concentration of the DNA extract were then checked 
using a NanoDrop Lite Spectrophotometer (Thermo Scientific, Waltham, MA). The target gene fragment was amplified in a reaction volume of $25 \mu \mathrm{L}$ containing $12.5 \mu \mathrm{L}$ of Taq DNA Polymerase 2.0× Master Mix Red (1.5 mM $\mathrm{MgCl}_{2}$; Ampliqon, Copenhagen, Denmark), $0.4 \mu \mathrm{mol} / \mathrm{L}$ of each primer, and 50 to $100 \mathrm{ng}$ of DNA template. The thermal cycling program consisted of 3 min at $94^{\circ} \mathrm{C}$, followed by 40 cycles of $1 \mathrm{~s}$ at $95^{\circ} \mathrm{C}, 30$ $\mathrm{s}$ at $55^{\circ} \mathrm{C}$, and $30 \mathrm{~s}$ at $72^{\circ} \mathrm{C}$, and the final elongation of $3 \mathrm{~min}$ at $72^{\circ} \mathrm{C}$. The amplified 370 -bp products were detected by electrophoresis in a $1.4 \%$ (wt/vol) agarose gel containing $0.5 \mu \mathrm{g} / \mathrm{mL}$ ethidium bromide in $1.0 \times$ Tris-acetate-EDTA buffer.

\section{Screening for Antimicrobial Activities}

The investigation of antimicrobial substance production was performed according to the agar spot test method described in a previous report (de Souza Duarte et al., 2013). In brief, $4 \mu \mathrm{L}$ of an overnight culture of each isolate was spotted onto a BHI agar plate. After $24 \mathrm{~h}$ of incubation at $37^{\circ} \mathrm{C}$, the colonies were inactivated by exposure to the chloroform vapor for $30 \mathrm{~min}$. Following the airing for $30 \mathrm{~min}$, BHI agar plates were overlaid with $4 \mathrm{~mL}$ of soft BHI agar $(0.6 \%$ wt/vol agar) seeded with $10^{5} \mathrm{cfu} / \mathrm{mL}$ of the indicator strain, incubated at $37^{\circ} \mathrm{C}$ for $24 \mathrm{~h}$, and examined for growth inhibition zones larger than $10 \mathrm{~mm}$. The target microorganism was Micrococcus luteus ATCC 4698, which is highly sensitive to the bacteriocins (Ceotto et al., 2009). Two bacteriocinogenic strains, Staph. aureus strain C55 (staphylococcin C55 producer) and Staph. epidermidis DSM 3095 (Tü 3298; epidermin producer), were used as positive controls. The experiments were carried out in 3 replicates.

\section{Characterization of the Antimicrobial Substances}

The proteinaceous nature of the antimicrobial compounds was determined by the method described by Giambiagi-Marval et al. (1990). Thus, the effects of trypsin, proteinase $\mathrm{K}$, protease XXIII, pronase, catalase (Sigma-Aldrich, St. Louis, MO), and $0.2 \mathrm{M} \mathrm{NaOH}$ (Merck) on antimicrobial substance activity against Micrococcus luteus ATCC 4698 were evaluated.

\section{Molecular Identification and Fingerprinting}

The identification of staphylococcal strains exhibiting bacteriocin production comprised 2 stages: (1) cluster analysis using a combination of random amplification of the polymorphic DNA (RAPD)-PCR and 16S-23S rRNA intergenic spacer region (ISR)-PCR patterns and (2) 16S rRNA or RNA polymerase B (rpoB) gene sequencing. The isolates were also subjected to pulsedfield gel electrophoresis (PFGE) genotyping to allow a more detailed examination of the genetic diversity.

$R A P D-P C R$ and ISR-PCR. The RAPD-PCR analysis was conducted with a 15-base primer M13 (5'-GAGGGTGGCGGTTCT-3') according to the PCR conditions given by Ruaro et al. (2013). The oligonucleotide primers and the amplification program applied in ISR-PCR assessment were the same as previously described by Mendoza et al. (1998). Cluster analysis using a combination of 2 different typing methods was carried out with the pattern analysis software package GelCompar, version 4.0 (Applied Math, Kortrijk, Belgium). The obtained patterns were compared using Pearson's product-moment correlation coefficient and the unweighted pair group method with arithmetic averages (Simeoni et al., 2008; Ruaro et al., 2013).

rpoB and $16 S$ rRNA Gene Sequencing. The isolates with unique profiles and a representative number of isolates from each cluster were further characterized by the amplification of the $5^{\prime}$ end $16 \mathrm{~S}$ rRNA gene with the universal primers E8F (5'-AGAGTTTGATCCTGGCTCAG-3') and E1541R (5'-AAGGAGGTGATCCANCCRCA-3'; Baker et al., 2003). The thermal profile comprised an initial denaturing step of $5 \mathrm{~min}$ at $94^{\circ} \mathrm{C}$, followed by 30 cycles of $30 \mathrm{~s}$ at $95^{\circ} \mathrm{C}, 30 \mathrm{~s}$ at $59^{\circ} \mathrm{C}$, and $90 \mathrm{~s}$ at $72^{\circ} \mathrm{C}$, and a final extension step of $72^{\circ} \mathrm{C}$ for $10 \mathrm{~min}$. For the isolates not identified by $16 \mathrm{~S}$ rRNA sequence analysis, the partial rpoB gene (899 bp) sequences were determined by the use of primers $1418 \mathrm{f}$ (5'-CAATTCATGGACCAAGC-3') and 3554r (5'-CCGTCCCAAGTCATGAAAC-3'; Mellmann et al., 2006). The DNA sequencing of the reaction products purified with ethanol precipitation was performed at GATC Biotech (Konstanz, Germany) using the corresponding forward PCR primer. The 16S rRNA sequencing results underwent preliminary analysis against the EzTaxon database (http://www.ezbiocloud.net/eztaxon) to identify the closest phylogenetic relatives, and the rрoB gene sequences were aligned using GenBank (https:// blast.ncbi.nlm.nih.gov/Blast.cgi).

PFGE. The PFGE profiles were obtained by the method introduced by Jorgensen et al. (1996). Electrophoresis was performed using the CHEF Mapper system (Bio-Rad Laboratories, Hercules, CA) with a switch time increased from $2 \mathrm{~s}$ to $35 \mathrm{~s}$ over $21 \mathrm{~h}$ at $13^{\circ} \mathrm{C}$ at a constant voltage of $6 \mathrm{~V} / \mathrm{cm}$ (Santos et al., 1999; de Souza Duarte et al., 2013). XbaI-digested genomic DNA of Salmonella serotype Braenderup H9812 was used as the molecular size marker (Hunter et al., 2005). The band profiles were then analyzed with BioNumerics software (version 7.1; Applied Math, Sint-Martens- 
Latem, Belgium) using the unweighted pair group method with arithmetic averages clustering method with the band-based Dice similarity coefficient.

\section{Detection of Staphylococcin Structural Genes}

We carried out PCR amplification to detect the structural genes of known staphylococcins (aureocin A70, aureocin A53, staphylococcin C55, Pep5, epidermin, epilancin K7, epicidin 280, nukacin ISK-1, and Bsa) using the primers and conditions indicated by de Souza Duarte et al. (2013). The primers used for each gene, the annealing temperature for each set of primer pairs, and the expected size of the product amplified are listed in Table 1. Each individual PCR mixture comprised 1× PCR buffer (Sigma-Aldrich), 2 to $3 \mathrm{mM}$ $\mathrm{MgCl}_{2}$ (Sigma-Aldrich), $1 \mu \mathrm{mol} / \mathrm{L}$ of each primer, 200 $\mu M$ dNTP (Sigma-Aldrich), 1.25 U of Taq DNA polymerase (Sigma-Aldrich), and 50 to $100 \mathrm{ng}$ of genomic DNA in a final volume of $25 \mu \mathrm{L}$. The PCR fragments were then sequenced in both strands (GATC Biotech), and homology search was made with BLAST (https: //blast.ncbi.nlm.nih.gov/Blast.cgi). Staphylococcus aureus C55 and Staph. epidermidis DSM 3095 were used as reference strains.

\section{Cross-Immunity Assessment}

Functionally related bacteriocins have been shown to exhibit cross-immunity (dos Santos Nascimento et al., 2005; Ceotto et al., 2009; Fagundes et al., 2011; de Souza Duarte et al., 2013). Therefore, the antagonistic activity of all the bacteriocin-producing strains, including fresh isolates from raw milk samples, as well as 2 reference strains (Staph. aureus C55 and Staph. epidermidis DSM 3095) against each other was investigated using the agar spot test method.

\section{Inhibitory Spectrum}

The agar spot test was also used to evaluate the antimicrobial activity of bacteriocinogenic isolates and 2 reference strains against several food spoilage and pathogenic organisms: Bacillus cereus (from readyto-eat food), Listeria monocytogenes ATCC 1297, L. monocytogenes R4S88, Enterococcus faecalis Ef37, Lactobacillus saerimneri 30a, Salmonella enterica serovar Typhimurium ATCC 14028, Escherichia coli O157:H7 ATCC 43895, E. coli O157:H7 R4S96, Klebsiella pneumonia ATCC 700603, and Aspergillus fumigatus PTCC 5009. The indicator strains L. monocytogenes R4S88 and E. coli O157:H7 R4S96 have been isolated from the same milk samples. Enterococcus faecalis Ef37 is a tyramine-producer strain isolated from traditional Italian goat cheese. Lactobacillus saerimneri 30a (formerly known as Lactobacillus 30a), an isolate from the horse stomach, is able to produce histamine from histidine.

\section{RESULTS}

\section{Screening for Bacteriocin Production}

Among a total of 243 staphylococcal strains isolated from milk samples, 28 isolates from 19 different herds were found to produce antimicrobial substances. The diameter of the inhibition zones ranged from 10 to 43 $\mathrm{mm}$, and about $54 \%$ were larger than $36 \mathrm{~mm}$ (Figure 1). Treatment with sodium hydroxide and catalase

Table 1. The primers used for detection of genes encoding known staphylococcins (de Souza Duarte et al., 2013)

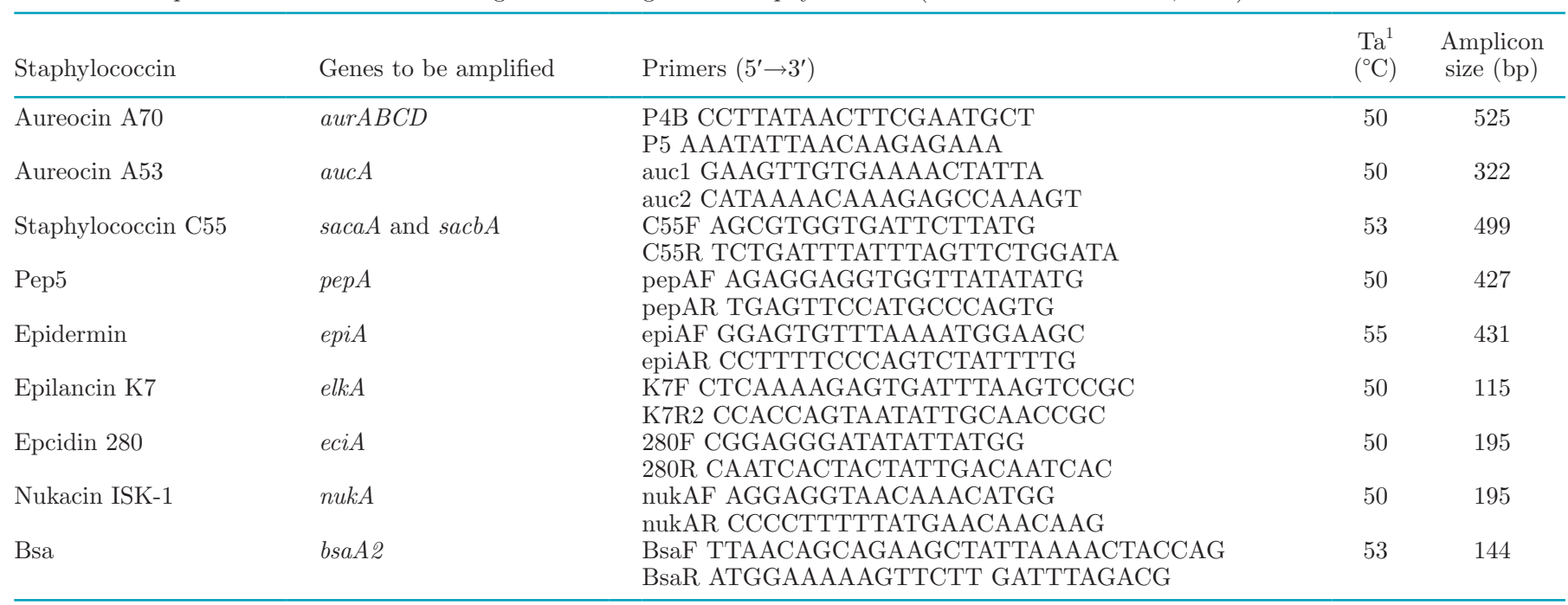

\footnotetext{
${ }^{1}$ Annealing temperature.
} 

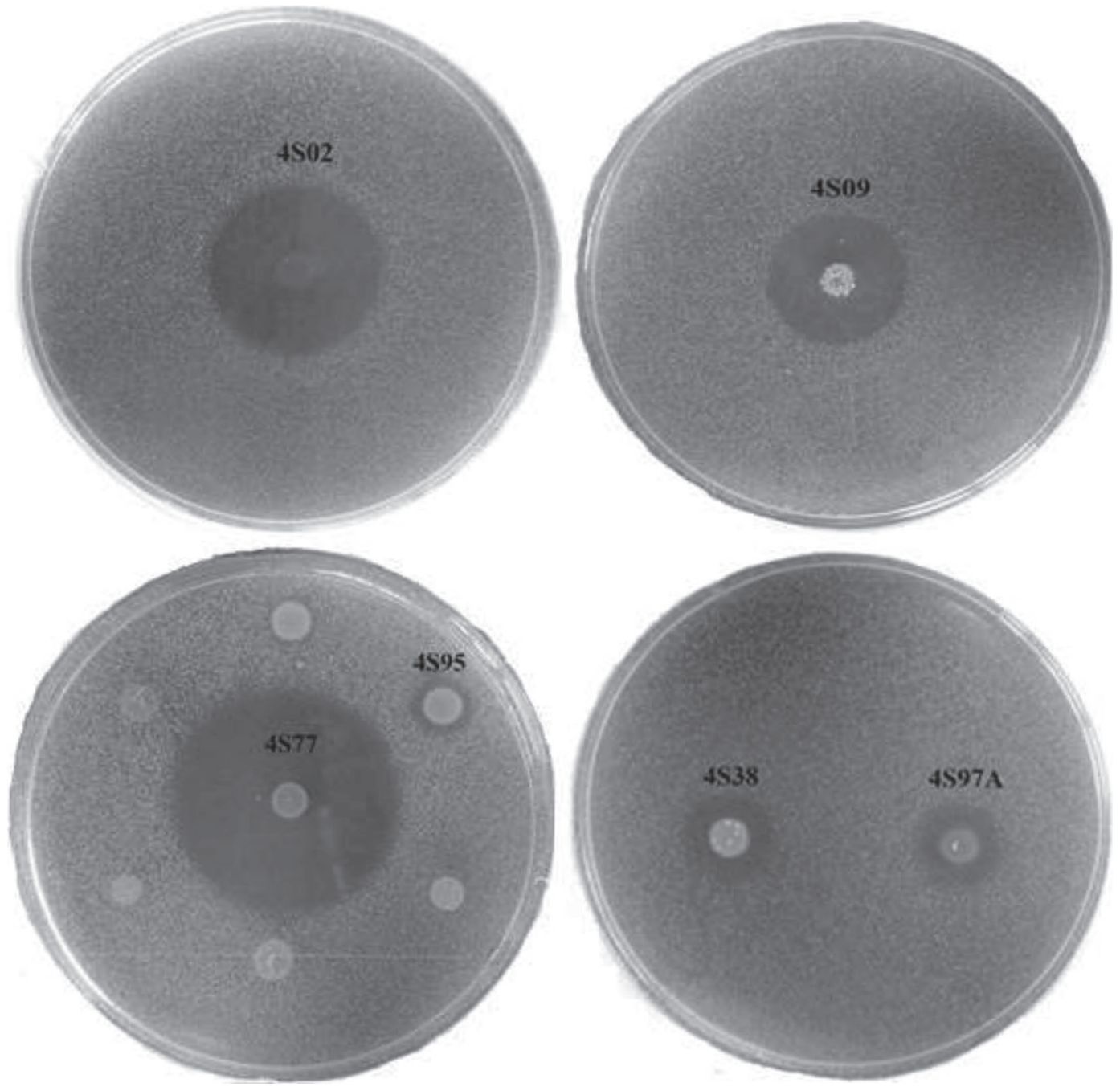

Figure 1. Agar spot test showing the growth inhibition of Micrococcus luteus ATCC 4698 by representative Staphylococcus strains: 4S02, Staph. epidermidis; 4S09, Staph. epidermidis; 4S77, Staph. chromogenes; 4S95, Staph. aureus; 4S38, Staph. haemolyticus; 4S97A, Staph. pseudintermedius.

had no effect on the activity of all the antimicrobial compounds, but they were sensitive to at least 1 of the proteolytic enzymes tested; this confirms their proteinaceous nature, which means that these biologically active compounds could be referred to as BLIS.

\section{Molecular Identification and Fingerprinting}

By combining the 2 molecular typing methods, RAPD-PCR and ISR-PCR, a total of 16 different profiles were obtained from the 28 staphylococcal isolates (Figure 2). The isolates with identical band patterns were designated as the same genotype. At a relative genetic similarity of $65 \%$, the isolates were divided into 5 major clusters and a single profile. Based on the results of cluster analysis and rpoB or $16 \mathrm{~S}$ rRNA gene sequenc- ing, strains belonging to genotypes 1 to 3 and 13 were identified as Staph. epidermidis $(\mathrm{n}=7)$. The 11 strains included in genotypes 5 to 11 were distinguished as Staphylococcus chromogenes. The isolates confirmed as Staphylococcus haemolyticus $(\mathrm{n}=6)$ were of the same genotype (genotype 14) except for isolate 4S35, which showed unique fingerprints. The remaining 4 isolates were recognized as Staphylococcus pseudintermedius (n $=2)$, Staph. aureus $(\mathrm{n}=1)$, and Staphylococcus agnetis $(\mathrm{n}=1)$.

Isolates belonging to the same species were further compared by PFGE. The results of PFGE analysis of the SmaI-digested DNA are shown in Figure 3. At the 90\% similarity level, the Staph. chromogenes isolates were divided into 6 pulsotypes: A (subtypes $A_{1}$ and $\mathrm{A}_{2}$ ), B, C, D (subtypes $\mathrm{D}_{1}$ and $\mathrm{D}_{2}$ ), E, and F. The 
only bacteriocinogenic strain isolated from sampling region 3 (4S77) indicated the lowest genetic similarity value $(62 \%)$. Pulsotype $\mathrm{G}$ was the predominant pattern among the Staph. haemolyticus isolates, which was discriminated into 3 subtypes $\left(\mathrm{G}_{1}-\mathrm{G}_{3}\right)$ with more than $93 \%$ similarity; as expected, isolate $4 \mathrm{~S} 35$ showed a distant genetic relationship (about 63\% similarity) with the isolates included in pulsotype G. Although 2 Staph. pseudintermedius isolates originated from different herds, they exhibited an identical PFGE banding pattern (pulsotype I). The Staph. epidermidis isolates were linked at a similarity level of $37 \%$; among them, 4 isolates could not be differentiated from each other with the enzyme used in the present study. Isolates 4S01, 4S09, and 4S93, however, appeared to be distinct isolates of this species.

\section{Amplification of Staphylococcin Structural Genes}

The structural genes encoding aureocin A70, aureocin A53, staphylococcin C55, Pep5, epidermin, epilancin $\mathrm{K} 7$, and epicidin 280 were not detected in any of the BLIS-producing strains. A 195-bp fragment corresponding to the gene $n u k A$ was amplified in all isolates of Staph. epidermidis and Staph. haemolyticus as well as Staph. agnetis isolate, which showed a complete homology to the published sequences for the nukacin ISK-1 structural gene. However, only 4 isolates, including $4 \mathrm{~S} 02,4 \mathrm{~S} 08 \mathrm{~A}, 4 \mathrm{~S} 13 \mathrm{~B}$, and $4 \mathrm{~S} 25$, presented strong amplicons of the expected size without any nonspecific bands (Figure 4a). The 4S01, 4S09, 4S38, and 4S97B isolates also revealed the presence of the gene bsaA2. A weak DNA band of the size expected for $b s a A 2$ was found in the isolates belonging to the species of Staph. chromogenes, Staph. pseudintermedius, and Staph. aureus as well (Figure 4b). The BLAST analysis of PCR products indicated a high degree of identity with the genes encoding gallidermin and epidermin.

\section{Cross-Immunity}

The results of cross-immunity assays summarized in Table 2 indicated that all of the BLIS-producing strains exhibited immunity to their own antimicrobial
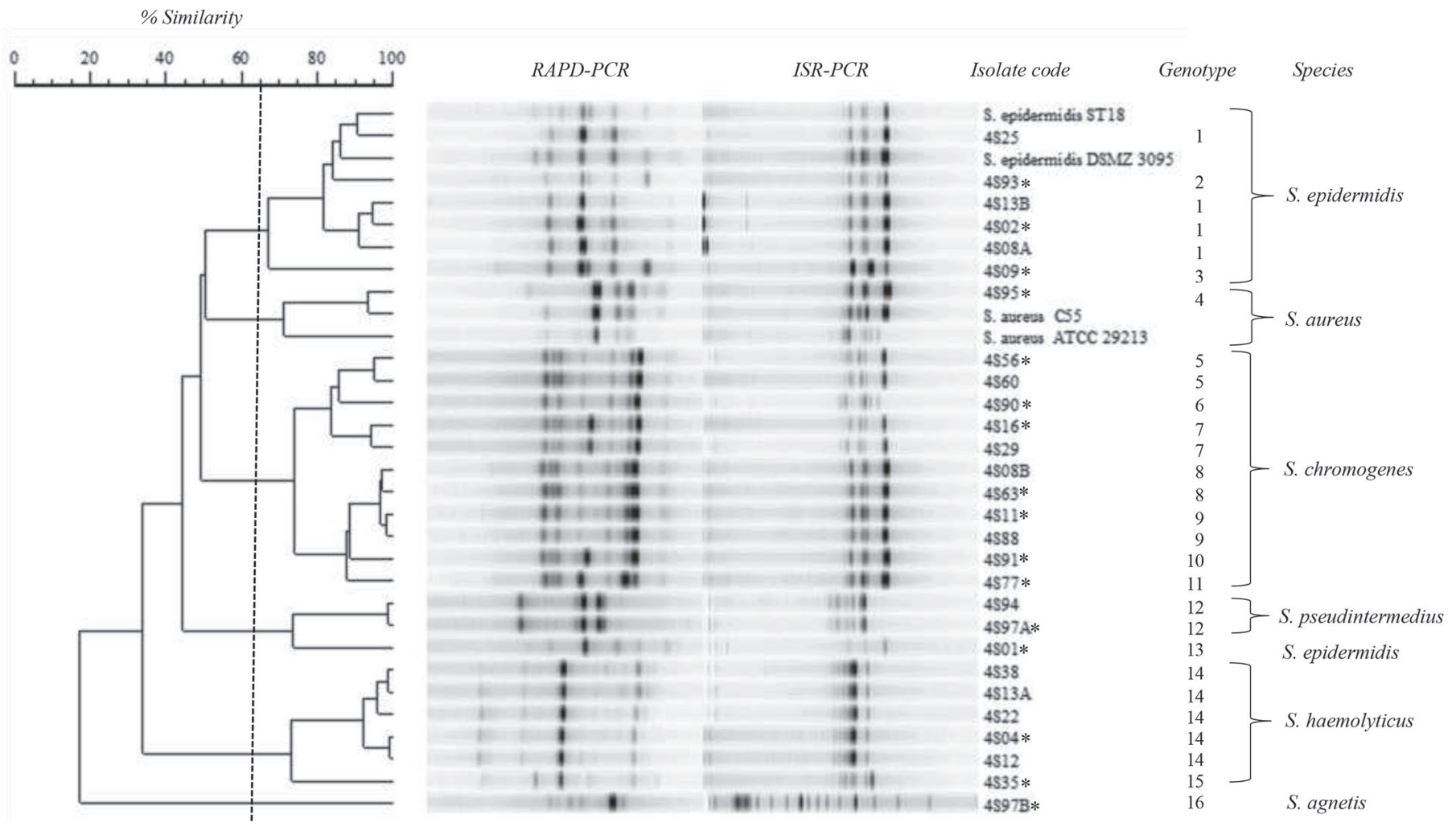

Figure 2. Unweighted pair group method with arithmetic averages dendrogram obtained from the combined analysis of M13 random amplification of the polymorphic DNA (RAPD)-PCR and 16S-23S rRNA intergenic spacer region (ISR)-PCR profiles of the bacteriocin-like inhibitory substance-producing Staphylococcus strains. The scale bar represents the percentage of similarity, and the vertical dotted line indicates the $65 \%$ similarity level for clustering the isolates. Restriction patterns with a similarity index of $<90 \%$ were classified as different genotypes with the exception of isolate $4 \mathrm{~S} 25$ analyzed by visual interpretation of the banding patterns. Asterisks $(*)$ indicate identification by $16 \mathrm{~S}$ rRNA and RNA polymerase B (rpoB) gene sequencing. 
agents. All of the Staph. chromogenes isolates showed identical inhibitory profiles regardless of pulsotypes, indicating a possible relatedness between their BLIS. Considering the Staph. epidermidis strains, the profiles were pulsotype dependent. The inhibitory substances produced by the Staph. chromogenes isolates inhibited the growth of all the strains belonging to other species, including the 2 reference strains (Staph. aureus C55 and Staph. epidermidis DSM 3095), suggesting the apparent distinction of these compounds from staphylococcin C55, epidermin, and BLIS from the other tested strains. The inhibitory compounds of all the isolates of Staph. epidermidis, except for isolate 4S01, seem to be related - but not identical - to each other and to those of Staph. aureus C55 and Staph. epidermidis DSM 3095. Staphylococcus haemolyticus and Staph. pseudintermedius isolates were the only strains not affected by BLIS
4S01, showing the presence of cross-immunity between these strains. The BLIS produced by the 4S97B strain was probably different from staphylococcin C55. The BLIS-producing strains belonging to the species Staph. haemolyticus, Staph. pseudintermedius, and Staph. aureus were not able to inhibit or be inhibited by Staph. aureus C55 and Staph. epidermidis DSM 3095, which may reflect relatedness among their respective antimicrobial substances.

\section{Inhibitory Spectrum}

The inhibitory effect of the isolates on the growth of target organisms is shown in Table 3. None of the bacteriocinogenic isolates was able to inhibit gram-negative pathogens. They also showed no activity against A. fumigatus. All of the Staph. chromogenes isolates ex-

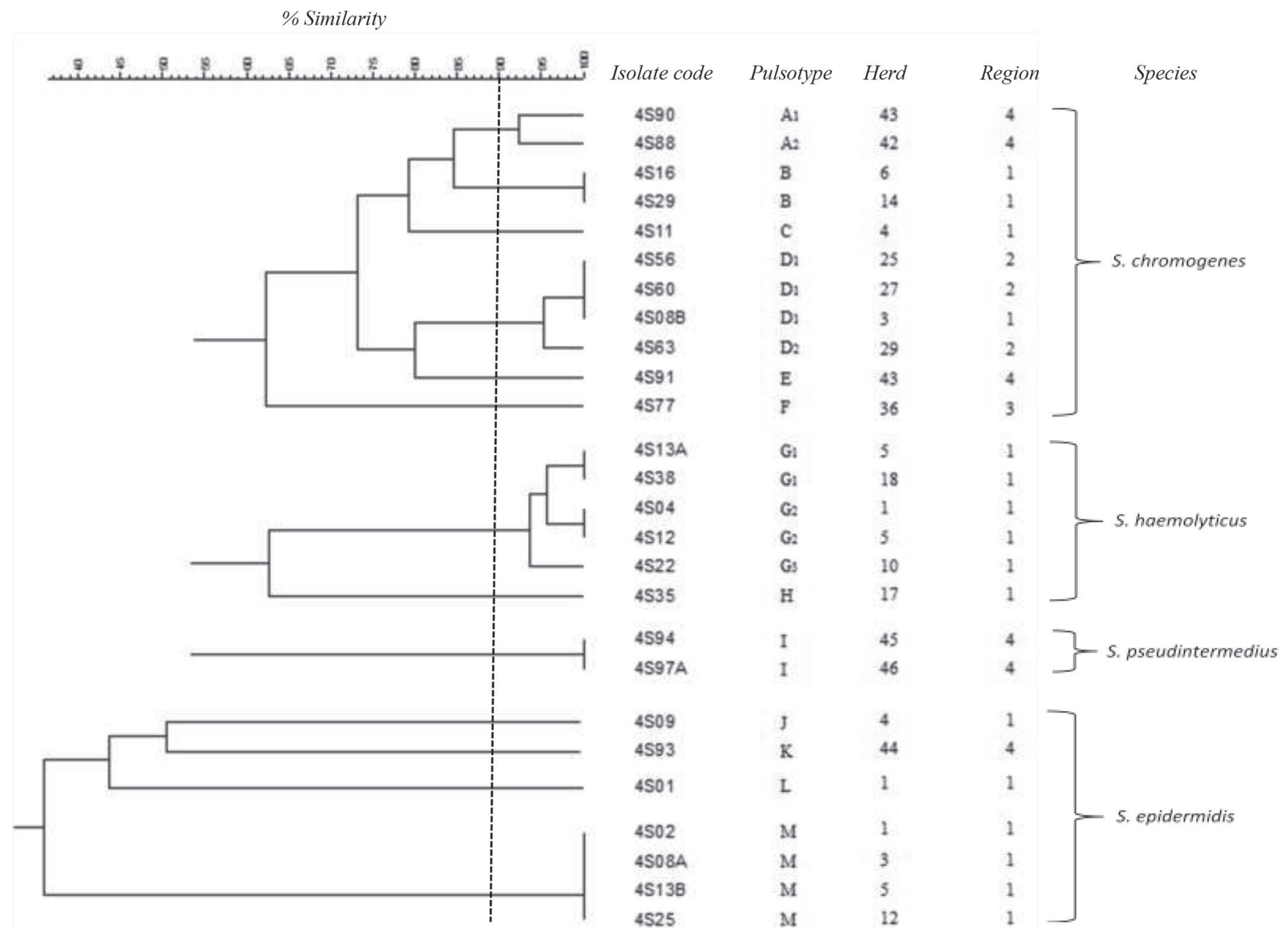

Figure 3. Dendrogram showing the genotypic relatedness of bacteriocin-like inhibitory substance-producing Staphylococcus strains based on SmaI-pulsed-field gel electrophoresis fingerprints. A Dice coefficient and the unweighted pair group method using arithmetic averages clustering algorithm were used with position tolerance and optimization both set at $1 \%$. The scale bar represents the percentage of similarity, and the vertical dotted line indicates the $90 \%$ similarity level for comparative purposes. 
hibited an inhibitory activity against the gram-positive target strains. They also gave similar inhibition zone diameter against the same indicator strain. Listeria monocytogenes ATCC 1297 and Lac. saerimneri 30a were the most and least sensitive strains to the BLIS produced by Staph. chromogenes isolates, respectively. The isolate 4S12 was the only Staph. haemolyticus strain able to inhibit the majority of gram-positive strains used in the present study. It showed the average inhibition zones larger than $2.0 \mathrm{~cm}$ against L. monocytogenes strains. Staphylococcus agnetis 4S97B was only antagonistic to L. monocytogenes strains with an inhibition zone diameter of $1.0 \mathrm{~cm}$. All indicator strains were resistant to the BLIS produced by Staph. epidermidis, Staph. pseudintermedius, and Staph. aureus strains. The positive control strains, Staph. aureus C55 and Staph. epidermidis DSM 3095, inhibited a low percentage of gram-positive indicators (17 and $33 \%$, respectively).

\section{DISCUSSION}

Reports on the prevalence of bacteriocin-producing strains among Staphylococcus isolates from different sources varied from $6 \%$ to $51 \%$ (Giambiagi-Marval et al., 1990; dos Santos Nascimento et al., 2005; Ceotto et al., 2009; Brito et al., 2011; Fagundes et al., 2011; de Souza Duarte et al., 2013; Braem et al., 2014). However, no information is available on the bacteriocinogenic potential of the Staphylococcus strains recovered from small ruminants. In the current study, $11.5 \%$ of the isolates exhibited high bacteriocin activity against the indicator organism M. luteus ATCC 4698. The isolates belonging to the same species showed similar inhibition zone diameters, with the exception of the Staph. epidermidis group. The PFGE type M Staph. epidermidis strains with the average inhibition zone of $39 \mathrm{~mm}$ were found to be positive for the gene nukA encoding nukacin ISK-1. Nukacin-type bacteriocins have been previously reported in Staphylococcus species other than Staph. epidermidis, including Staph. warneri (Sashihara et al., 2000; Minamikawa et al., 2005), Staph. hominis (Wilaipun et al., 2008), Staphylococcus simulans (Ceotto et al., 2010b), and Staph. chromogenes (Braem et al., 2014). Because bacteriocin production is often linked with the mobile genetic elements (Hurtado et al., 2011), the results suggest the possibility of horizontal transfer of the bacteriocin genes among different Staphylococcus species. Four pulsotype M isolates originated from the same region but from different herds and displayed a similar inhibitory profile, which might indicate the identity of their antimicrobial agent. They were not able to inhibit or be inhibited by Staph. epidermidis DSM 3095 (the epidermin-producer strain). In the study conducted by dos Santos Nascimento et al. (2005), although the nukacin-producer strain Staph. simulans 3299 did not inhibit this epidermin producer, its growth was negatively affected by Staph. epidermidis DSM 3095. Therefore, compared with Staph. simulans a

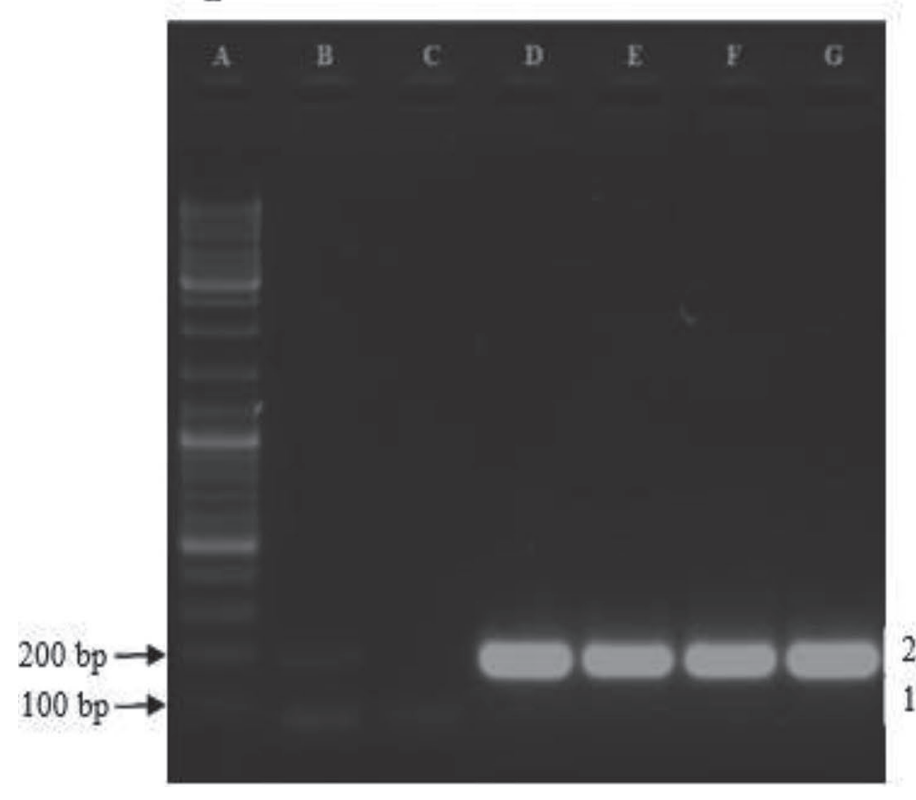

b

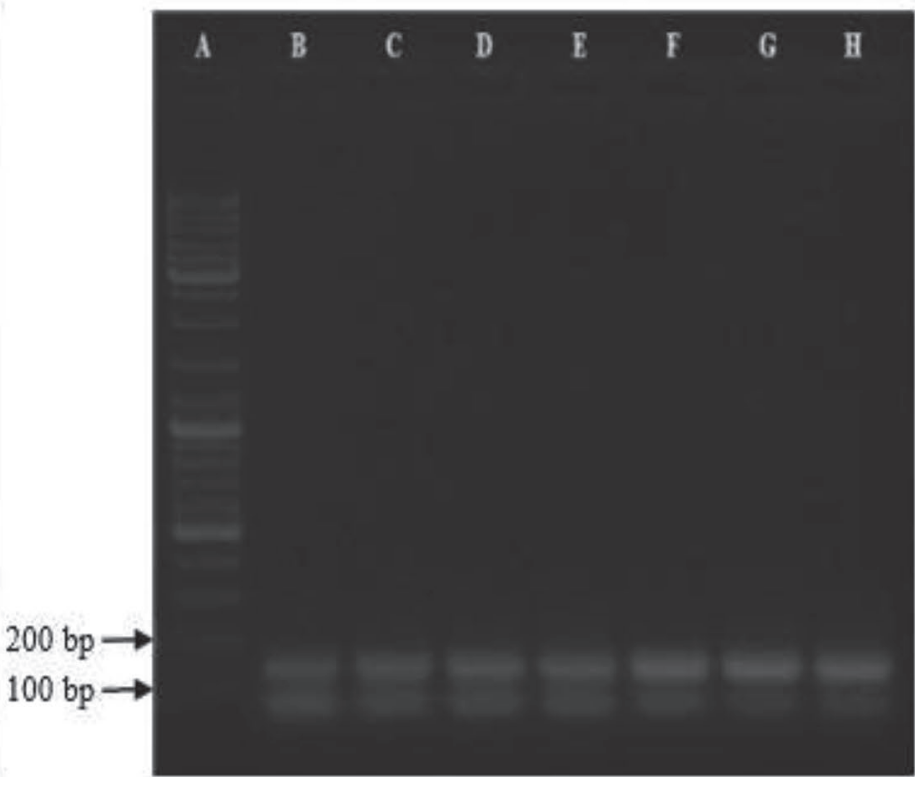

Figure 4. (a) Representative PCR amplification of the nukA gene encoding nukacin ISK-1. A: 100-bp DNA ladder; B: 4S35; C: negative control; D: 4S02; E: 4S08A; F: 4S13B; G: 4S25. (b) Representative PCR amplification of the bsaA2 gene encoding Bsa. A: 100-bp DNA ladder; B: 4S01; C: 4S09; D: 4S38; E: 4S77; F: 4S94; G: 4S95; H: 4S97B. 
RAHMDEL ET AL.

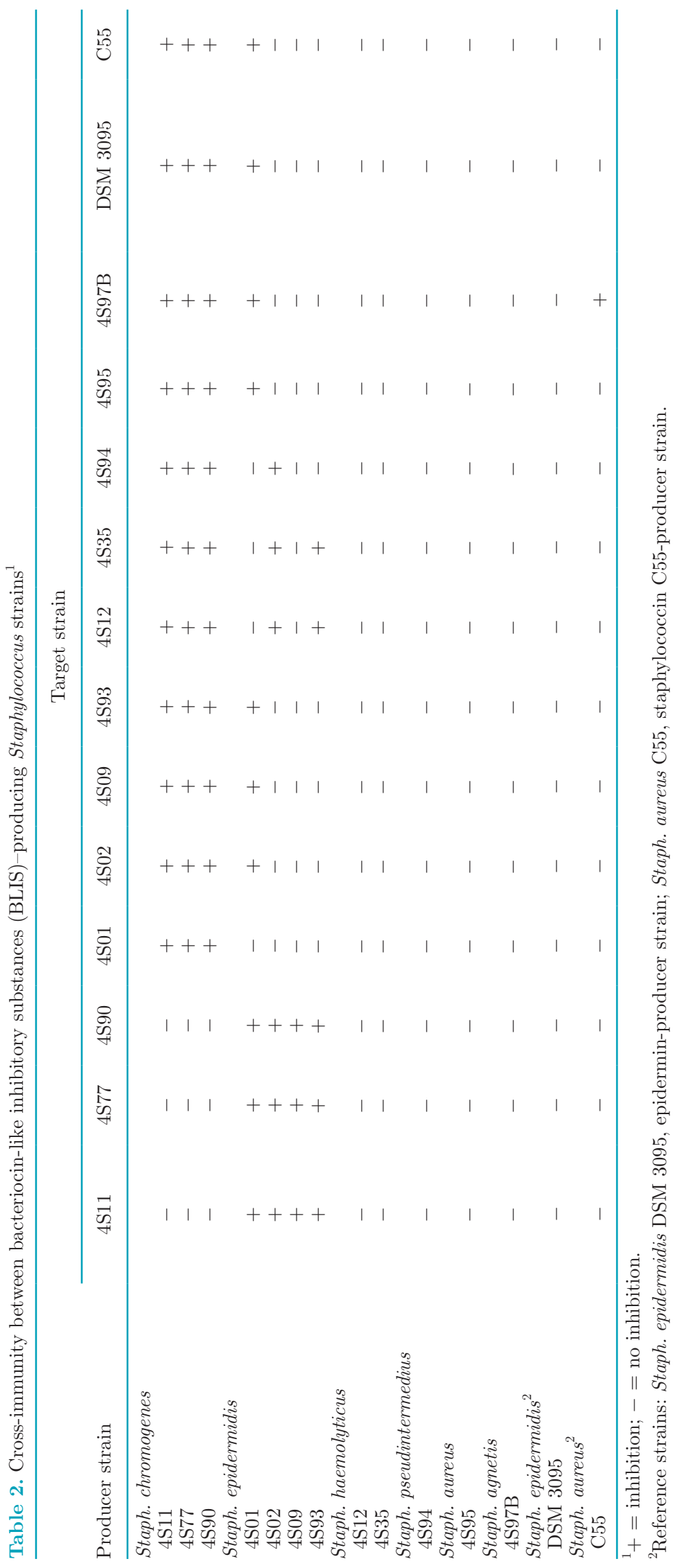


3299 , the nukacin producer isolates obtained in this study seem to have either a more efficient immunity system or much resistance against epidermin, the confirmation of which awaits further experiments.

A weak band of the expected size for $n u k A$ was detected in all Staph. haemolyticus (a mean inhibition zone of $14 \mathrm{~mm}$ ) and Staph. agnetis (inhibition zone of $11 \mathrm{~mm}$ ) isolates and in other Staph. epidermidis strains belonging to different pulsotypes. Several these isolates (4S01, 4S09, 4S38, and 4S97B) showed a weak band during the amplification of the gene bsaA2 as well. These strains seem to produce bacteriocins related to nukacin ISK-1 and Bsa (an epidermin-like bacteriocin); their inhibitory activities against each other and against 2 reference strains revealed that the antimicrobial substances were unrelated. It is worth mentioning that although similar bacteriocins produced by different strains generally display cross-immunity, a few researchers have reported opposite findings (Daly et al., 2010). Despite the discovery of bacteriocin production in numerous species of Staphylococcus, to the best of our knowledge, no such activity has ever been reported in Staph. agnetis.

There is little evidence of antibacterial activity in Staph. chromogenes, and to date nukacin L217 is the only well-characterized bacteriocin in this species, which is identical to the other nukacin-type bacteriocins (Braem et al., 2014). However, the BLIS of Staph. chromogenes isolates investigated in this study are assumed to be different from nukacin ISK-1 and its natural variants because none of them were positive for the gene $n u k A$. Moreover, these strains and pulsotype M Staph. epidermidis isolates (producers of nukacin-type bacteriocins) did not exhibit cross-immunity to each other. These 11 isolates of Staph. chromogenes originated from 10 different herds located in geographically distant regions in Fars province and belonged to different pulsotypes; all of them, however, exhibited identical inhibitory profiles and similar zone sizes $(38-40 \mathrm{~mm})$ and conferred crossimmunity to each other. Their relevant bacteriocins, therefore, seem to be similar. Besides, the gene bsaA2 was present in all the strains, which, not surprisingly, showed a high level of homology to the genes encoding gallidermin and epidermin. The inhibitory agents of Staph. chromogenes isolates could be consequently considered to be epidermin-like bacteriocins.

The bsaA2 gene was also found in the coagulasepositive species Staph. aureus and Staph. pseudintermedius. Few bacteriocins from the latter species have been described in the literature and seem to be different from each other. A well-characterized bacteriocin is a protease-resistant peptide designated as BacSp222, whereas the other one is sensitive to the proteolytic enzymes (Pinto et al., 2013; Wladyka et al., 2015). In 
the present study, the isolates of Staph. pseudintermedius and Staph. haemolyticus exhibited cross-immunity with strain 4S01 from the Staph. epidermidis group, which inhibited the growth of all the other isolates. The PFGE typing revealed that strain 4S01 was more related to the Staph. pseudintermedius and Staph. haemolyticus clusters than to other strains of Staph. epidermidis (data not shown), which can vindicate the cross-immunity between these isolates. Furthermore, they showed a comparable zone of inhibition (10-14 $\mathrm{mm})$. Although the unique inhibitory profile of BLIS 4S01 precludes us from considering it as identical to the antimicrobial agents produced by Staph. pseudintermedius and Staph. haemolyticus, they may be related to some extent.

Bacteriocins are generally active against closely related species, which could explain the inefficiency of test isolates in inhibiting gram-negative bacteria and the indicator mold A. fumigatus (Bastos et al., 2009). In total, the literature on the inhibitory spectrum of staphylococcins indicates their efficiency against $B$. cereus and L. monocytogenes (Villani et al., 1997; Carnio et al., 2000; dos Santos Nascimento et al., 2005; Prema et al., 2006; Saeed et al., 2006; Ceotto et al., 2009, 2010a; Brito et al., 2011; Fagundes et al., 2011; de Souza Duarte et al., 2013; Fagundes et al., 2016). Compared with the partially purified staphylococcin from Staph. aureus AB188, Bac188 (which has been found to produce only a weak zone of inhibition against $B$. cereus; Saeed et al., 2006), Staph. chromogenes isolates investigated in our study exhibited a remarkable antagonistic activity against this indicator strain. The inhibitory effect of Staph. haemolyticus $4 \mathrm{~S} 12$ on B. cereus was similar to that of Staph. epidermidis DSM 3095.

The antilisterial activity of the BLIS from Staph. chromogenes isolates and Staph. haemolyticus 4S12 seems to be comparable with that found by de Souza Duarte et al. (2013) for staphylococcins aureocin A70 and hyicin 4244 with inhibition zone diameters of 2.1 to $>3 \mathrm{~cm}$. However, a less antilisterial action has been reported for warnerin, produced by Staph. warneri (Prema et al., 2006), and aureocin A70, produced by Staph. aureus A70 (inhibition zone diameters of 1.75 to $2.05 \mathrm{~cm}$; Fagundes et al., 2016).

Much less has been published regarding the antimicrobial effects of Staphylococcus strains on the amine producers (Mah and Hwang, 2009). In a complementary study (Rahmdel et al., 2018), Staph. epidermidis 4S93 was found to be resistant to methicillin. The antimicrobial compounds of Staph. chromogenes isolates also exhibited an inhibitory effect against this strain, suggesting their potential application as antibiotic alternatives.
The BLIS from pulsotype M Staph. epidermidis isolates were unable to inhibit any of the bacterial species tested. These strains produce nukacin-type bacteriocins that have been shown to be effective against Listeria innocua, Bacillus subtilis, and Streptococcus bovis as well as mastitis-causing pathogens (Streptococcus spp. and Staph. aureus) but not E. coli (Asaduzzaman et al., 2009; Braem et al., 2014; Roy et al., 2014). These bacteriocins can therefore be used to target particular organisms.

\section{CONCLUSIONS}

The indications for the application of staphylococcins as alternatives to the current antibiotics and food preservatives are promising but less established. In the present study, 28 bacteriocinogenic Staphylococcus isolates were recovered from raw milk of goats and sheep, belonging to the species Staph. chromogenes, Staph. epidermidis, Staph. haemolyticus, Staph. pseudintermedius, Staph. aureus, and Staph. agnetis. Four Staph. epidermidis isolates belonging to the same pulsotype (M) seemed to produce nukacin-type bacteriocins, which have previously been reported in other Staphylococcus species. The antimicrobial compounds produced by the other isolates were found to be related, but not identical, to nukacin or Bsa. The Staph. chromogenes isolates, Staph. haemolyticus 4S12, and Staph. agnetis 4S97B displayed a remarkable antagonistic activity against $B$. cereus and L. monocytogenes. Furthermore, little evidence is available on the inhibitory effects of staphylococcins against amine-producing strains, the growth of which was inhibited by the antimicrobial compounds of all the Staph. chromogenes isolates and Staph. haemolyticus 4S12. Given the spectrum of activity of the BLIS produced by the Staph. chromogenes isolates and Staph. haemolyticus 4S12, they have the potential to be used for biocontrol of food spoilage and pathogenic organisms. The antimicrobial substances of Staph. chromogenes strains appear to be active toward antibiotic-resistant infections as well. However, they need to be fully characterized in the context of their safety, efficacy, and ease of use in food systems or patients. On the other hand, the BLIS-related gene cluster can be inserted into a suitable host with a potential to be used as a food starter culture.

\section{ACKNOWLEDGMENTS}

This study was financially supported by Shiraz University (Shiraz, Iran). The authors express their gratitude to Colin Hill and Des Field (University College Cork, Cork, Ireland) for kindly providing the strains of 
Staphylococcus aureus C55 and Staphylococcus epidermidis DSM 3095 as well as to Fabio Fracchetti (Microbion, spin-off of the University of Verona, Verona, Italy) for his technical assistance. Special thanks are also due to M. C. Bastos (Federal University of Rio de Janeiro, Brazil) for her helpful comments. Finally, the authors thank Mohammad Motamedifar (Shiraz University of Medical Sciences, Shiraz, Iran) for his invaluable technical support.

\section{REFERENCES}

Asaduzzaman, S. M., J.-I. Nagao, H. Iida, T. Zendo, J. Nakayama, and K. Sonomoto. 2009. Nukacin ISK-1, a bacteriostatic lantibiotic. Antimicrob. Agents Chemother. 53:3595-3598. https://doi.org/10 1128/AAC.01623-08

Baker, G. C., J. J. Smith, and D. A. Cowan. 2003. Review and reanalysis of domain-specific $16 \mathrm{~S}$ primers. J. Microbiol. Methods 55:541-555. https://doi.org/10.1016/j.mimet.2003.08.009.

Balciunas, E. M., F. A. C. Martinez, S. D. Todorov, B. D. G. de Melo Franco, A. Converti, and R. P. de Souza Oliveira. 2013. Novel biotechnological applications of bacteriocins: A review. Food Control 32:134-142. https://doi.org/10.1016/j.foodcont.2012.11.025.

Bastos, M. C., H. Ceotto, M. Coelho, and J. Nascimento. 2009. Staphylococcal antimicrobial peptides: Relevant properties and potential biotechnological applications. Curr. Pharm. Biotechnol. 10:38-61. https://doi.org/10.2174/138920109787048580.

Braem, G., B. Stijlemans, W. Haken, S. Vliegher, L. Vuyst, and F. Leroy. 2014. Antibacterial activities of coagulase-negative staphylococci from bovine teat apex skin and their inhibitory effect on mastitis-related pathogens. J. Appl. Microbiol. 116:1084-1093. https://doi.org/10.1111/jam.12447.

Brito, M. A., G. Somkuti, and J. Renye. 2011. Production of antilisterial bacteriocins by staphylococci isolated from bovine milk. J. Dairy Sci. 94:1194-1200. https://doi.org/10.3168/jds.2010-3849.

Carnio, M. C., A. Höltzel, M. Rudolf, T. Henle, G. Jung, and S. Scherer. 2000. The macrocyclic peptide antibiotic micrococcin P1 is secreted by the food-borne bacterium Staphylococcus equorum WS 2733 and inhibits Listeria monocytogenes on soft cheese. Appl. Environ. Microbiol. 66:2378-2384. https://doi.org/10.1128/AEM 66.6.2378-2384.2000

Ceotto, H., D. Brede, Z. Salehian, J. dos Santos Nascimento, P. C. Fagundes, I. F. Nes, and M. C. Bastos. 2010a. Aureocins 4185, bacteriocins produced by Staphylococcus aureus 4185: Potential application in food preservation. Foodborne Pathog. Dis. 7:1255-1262. https://doi.org/10.1089/fpd.2010.0578.

Ceotto, H., J. dos Santos Nascimento, M. A. V. de Paiva Brito, and M. C. Bastos. 2009. Bacteriocin production by Staphylococcus aureus involved in bovine mastitis in Brazil. Res. Microbiol. 160:592-599. https://doi.org/10.1016/j.resmic.2009.07.007.

Ceotto, H., H. Holo, K. F. S. Da Costa, J. dos Santos Nascimento, Z. Salehian, I. F. Nes, and M. C. Bastos. 2010b. Nukacin 3299, a lantibiotic produced by Staphylococcus simulans 3299 identical to nukacin ISK-1. Vet. Microbiol. 146:124-131. https://doi.org/10 .1016/j.vetmic.2010.04.032.

Daly, K. M., M. Upton, S. K. Sandiford, L. A. Draper, P. A. Wescombe, R. W. Jack, P. M. O'Connor, A. Rossney, F. Götz, and C. Hill. 2010. Production of the Bsa lantibiotic by community-acquired Staphylococcus aureus strains. J. Bacteriol. 192:1131-1142. https:/ /doi.org/10.1128/JB.01375-09.

de Souza Duarte, A. F., H. Ceotto, E. S. Barrias, T. C. B. S. Souto-Padrón, I. F. Nes, and M. C. Bastos. 2018. Hyicin 4244, the first sactibiotic described in staphylococci, exhibits an anti-staphylococcal biofilm activity. Int. J. Antimicrob. Agents 51:349-356. https:// doi.org/10.1016/j.ijantimicag.2017.06.025.

de Souza Duarte, A. F., H. Ceotto, M. L. V. Coelho, M. A. V. de Paiva Brito, and M. C. Bastos. 2013. Identification of new staphylococ- cins with potential application as food biopreservatives. Food Control 32:313-321. https://doi.org/10.1016/j.foodcont.2012.12.008.

dos Santos Nascimento, J., P. C. Fagundes, M. A. V. de Paiva Brito, K. R. N. Dos Santos, and M. C. Bastos. 2005. Production of bacteriocins by coagulase-negative staphylococci involved in bovine mastitis. Vet. Microbiol. 106:61-71. https://doi.org/10.1016/j vetmic.2004.10.014.

Fagundes, P. C., H. Ceotto, A. Potter, M. A. V. de Paiva Brito, D. Brede, I. F. Nes, and M. C. Bastos. 2011. Hyicin 3682, a bioactive peptide produced by Staphylococcus hyicus 3682 with potential applications for food preservation. Res. Microbiol. 162:1052-1059. https://doi.org/10.1016/j.resmic.2011.10.002.

Fagundes, P. C., F. M. de Farias, O. C. da Silva Santos, J. A. S. da Paz, H. Ceotto-Vigoder, D. S. Alviano, M. T. V. Romanos, and M. C. Bastos. 2016. The four-component aureocin A70 as a promising agent for food biopreservation. Int. J. Food Microbiol. 237:39-46. https://doi.org/10.1016/j.ijfoodmicro.2016.08.017.

Fontana, C., P. S. Cocconcelli, and G. Vignolo. 2005. Monitoring the bacterial population dynamics during fermentation of artisanal Argentinean sausages. Int. J. Food Microbiol. 103:131-142. https: //doi.org/10.1016/j.ijfoodmicro.2004.11.046.

García, P., L. Rodríguez, A. Rodríguez, and B. Martínez. 2010. Food biopreservation: Promising strategies using bacteriocins, bacteriophages and endolysins. Trends Food Sci. Technol. 21:373-382. https://doi.org/10.1016/j.tifs.2010.04.010.

Giambiagi-Marval, M., M. Mafra, E. Penido, and M. C. Bastos. 1990. Distinct groups of plasmids correlated with bacteriocin production in Staphylococcus aureus. J. Gen. Microbiol. 136:1591-1599. https: //doi.org/10.1099/00221287-136-8-1591.

Götz, F., S. Perconti, P. Popella, R. Werner, and M. Schlag. 2014. Epidermin and gallidermin: Staphylococcal lantibiotics. Int. J. Med. Microbiol. 304:63-71. https://doi.org/10.1016/j.ijmm.2013.08.012.

Hunter, S. B., P. Vauterin, M. A. Lambert-Fair, M. S. Van Duyne, K. Kubota, L. Graves, D. Wrigley, T. Barrett, and E. Ribot. 2005. Establishment of a universal size standard strain for use with the PulseNet standardized pulsed-field gel electrophoresis protocols: Converting the national databases to the new size standard. J. Clin. Microbiol. 43:1045-1050. https://doi.org/10.1128/JCM.43.3 .1045-1050.2005.

Hurtado, A., N. B. Othman, N. Chammem, M. Hamdi, S. Ferrer, C. Reguant, A. Bordons, and N. Rozès. 2011. Characterization of Lactobacillus isolates from fermented olives and their bacteriocin gene profiles. Food Microbiol. 28:1514-1518. https://doi.org/10 $.1016 / \mathrm{j} . \mathrm{fm} .2011 .07 .010$.

Jack, R. W., G. Bierbaum, and H.-G. Sahl. 1998. Lantibiotics and Related Peptides. Springer, Berlin, Germany.

Jorgensen, M., R. Givney, M. Pegler, A. Vickery, and G. Funnell. 1996. Typing multidrug-resistant Staphylococcus aureus: Conflicting epidemiological data produced by genotypic and phenotypic methods clarified by phylogenetic analysis. J. Clin. Microbiol. 34:398-403.

Kim, P. I., J. K. Sohng, C. Sung, H.-S. Joo, E.-M. Kim, T. Yamaguchi, D. Park, and B.-G. Kim. 2010. Characterization and structure identification of an antimicrobial peptide, hominicin, produced by Staphylococcus hominis MBBL 2-9. Biochem. Biophys. Res. Commun. 399:133-138. https://doi.org/10.1016/j.bbrc.2010.07.024.

Mah, J.-H., and H.-J. Hwang. 2009. Inhibition of biogenic amine formation in a salted and fermented anchovy by Staphylococcus xylosus as a protective culture. Food Control 20:796-801. https://doi .org/10.1016/j.foodcont.2008.10.005.

Mellmann, A., K. Becker, C. von Eiff, U. Keckevoet, P. Schumann, and D. Harmsen. 2006. Sequencing and staphylococci identification. Emerg. Infect. Dis. 12:333-336. https://doi.org/10.3201/eid1202 .050962 .

Mendoza, M., H. Meugnier, M. Bes, J. Etienne, and J. Freney. 1998. Identification of Staphylococcus species by $16 \mathrm{~S}-23 \mathrm{~S}$ rDNA intergenic spacer PCR analysis. Int. J. Syst. Bacteriol. 48:1049-1055. https://doi.org/10.1099/00207713-48-3-1049.

Minamikawa, M., Y. Kawai, N. Inoue, and K. Yamazaki. 2005. Purification and characterization of warnericin RB4, anti-Alicyclobacillus bacteriocin, produced by Staphylococcus warneri RB4. Curr. Microbiol. 51:22-26. https://doi.org/10.1007/s00284-005-4456-2. 
Morot-Bizot, S. C., R. Talon, and S. Leroy. 2004. Development of a multiplex PCR for the identification of Staphylococcus genus and four staphylococcal species isolated from food. J. Appl. Microbiol. 97:1087-1094. https://doi.org/10.1111/j.1365-2672.2004.02399.x.

Pinto, T. S., C. P. de Oliveira, A. C. V. da Costa, C. O. Lima, H. M. Barreto, E. L. de Souza, and J. P. Siqueira-Junior. 2013. Evidence for production of a bacteriocin-like substance by Staphylococcus pseudintermedius, inhibitory to Staphylococcus aureus from foods. Nat. Prod. Res. 27:1098-1101. https://doi.org/10.1080/14786419 .2012 .696260 .

Potter, A., H. Ceotto, M. L. V. Coelho, A. J. Guimarães, and M. C. Bastos. 2014. The gene cluster of aureocyclicin 4185: The first cyclic bacteriocin of Staphylococcus aureus. Microbiology 160:917928. https://doi.org/10.1099/mic.0.075689-0.

Prema, P., S. Bharathy, A. Palavesam, M. Sivasubramanian, and G. Immanuel. 2006. Detection, purification and efficacy of warnerin produced by Staphylococcus warneri. World J. Microbiol. Biotechnol. 22:865-872. https://doi.org/10.1007/s11274-005-9116-y.

Rahmdel, S., S. Hosseinzadeh, S. S. Shekarforoush, S. Torriani, V. Gatto, and S. Pashangeh. 2018. Safety hazards in bacteriocinogenic Staphylococcus strains isolated from goat and sheep milk. Microb. Pathog. 116:100-108. https://doi.org/10.1016/j.micpath .2018.01.016.

Roy, U., M. R. Islam, J.-I. Nagao, H. Iida, A.-A. Mahin, M. Li, T. Zendo, J. Nakayama, and K. Sonomoto. 2014. Bactericidal activity of nukacin ISK-1: An alternative mode of action. Biosci. Biotechnol. Biochem. 78:1270-1273. https://doi.org/10.1080/09168451.2014 .918485 .

Ruaro, A., C. Andrighetto, S. Torriani, and A. Lombardi. 2013. Biodiversity and characterization of indigenous coagulase-negative staphylococci isolated from raw milk and cheese of North Italy. Food Microbiol. 34:106-111. https://doi.org/10.1016/j.fm.2012.11 .013 .

Saeed, S., S. A. Rasool, S. Ahmed, T. Khanum, M. B. Khan, A. Abbasi, and S. A. Ali. 2006. New insight in staphylococcin research: Bacteriocin and/or bacteriocin-like inhibitory substance (s) produced by S. aureus AB188. World J. Microbiol. Biotechnol. 22:713-722. https://doi.org/10.1007/s11274-005-9095-z.

Sandiford, S., and M. Upton. 2012. Identification, characterization, and recombinant expression of epidermicin NI01, a novel unmodified bacteriocin produced by Staphylococcus epidermidis that dis- plays potent activity against staphylococci. Antimicrob. Agents Chemother. 56:1539-1547. https://doi.org/10.1128/AAC.05397 -11 .

Santos, K. R., L. M. Teixeira, G. Leal, L. S. Fonseca, and P. Gontijo Filho. 1999. DNA typing of methicillin-resistant Staphylococcus aureus: Isolates and factors associated with nosocomial acquisition in two Brazilian university hospitals. J. Med. Microbiol. 48:17-23. https://doi.org/10.1099/00222615-48-1-17.

Sashihara, T., H. Kimura, T. Higuchi, A. Adachi, H. Matsusaki, K. Sonomoto, and A. Ishizaki. 2000. A novel lantibiotic, nukacin ISK1, of Staphylococcus warneri ISK-1: Cloning of the structural gene and identification of the structure. Biosci. Biotechnol. Biochem. 64:2420-2428. https://doi.org/10.1271/bbb.64.2420.

Simeoni, D., L. Rizzotti, P. Cocconcelli, S. Gazzola, F. Dellaglio, and S. Torriani. 2008. Antibiotic resistance genes and identification of staphylococci collected from the production chain of swine meat commodities. Food Microbiol. 25:196-201. https://doi.org/10 .1016/j.fm.2007.09.004.

Varella Coelho, M. L. V., J. dos Santos Nascimento, P. C. Fagundes, D. J. Madureira, S. S. de Oliveira, M. A. V. de Paiva Brito, and M. C. Bastos. 2007. Activity of staphylococcal bacteriocins against Staphylococcus aureus and Streptococcus agalactiae involved in bovine mastitis. Res. Microbiol. 158:625-630. https://doi.org/10 .1016/j.resmic.2007.07.002.

Villani, F., L. Sannino, G. Moschetti, G. Mauriello, O. Pepe, R. Amodio-Cocchieri, and S. Coppola. 1997. Partial characterization of an antagonistic substance produced by Staphylococcus xylosus 1E and determination of the effectiveness of the producer strain to inhibit Listeria monocytogenes in Italian sausages. Food Microbiol. 14:555-566. https://doi.org/10.1006/fmic.1997.0129.

Wilaipun, P., T. Zendo, K.-I. Okuda, J. Nakayama, and K. Sonomoto. 2008. Identification of the nukacin KQU-131, a new type-A (II) lantibiotic produced by Staphylococcus hominis KQU-131 isolated from Thai fermented fish product (Pla-ra). Biosci. Biotechnol. Biochem. 72:2232-2235. https://doi.org/10.1271/bbb.80239.

Wladyka, B., M. Piejko, M. Bzowska, P. Pieta, M. Krzysik, Ł. Mazurek, I. Guevara-Lora, M. Bukowski, A. J. Sabat, and A. W. Friedrich. 2015. A peptide factor secreted by Staphylococcus pseudintermedius exhibits properties of both bacteriocins and virulence factors. Sci. Rep. 5:14569. https://doi.org/10.1038/srep14569. 